\title{
A nearly complete ornithocheirid pterosaur from the Aptian (Early Cretaceous) Crato Formation of NE Brazil
}

\author{
Ross A. Elgin and Eberhard Frey \\ Acta Palaeontologica Polonica 57 (1), 2012: 101-110 doi: http://dx.doi.org/10.4202/app.2010.0079
}

A partial ornithocheirid, representing a rare example of a pterosaurian body fossil from the Nova Olinda Member of the Crato Formation, NE Brazil, is described from the collections of the State Museum of Natural History, Karlsruhe. While similar in preservation and taphonomy to Arthurdactylus conandoylei, it is distinguished by slight differences in biometric ratios, but the absence of a skull prevents closer identification. Mostly complete body fossils belonging to ornithocheiroid pterosaurs appear to be relatively more abundant in the younger Romualdo Member of the Santana Formation, making the described specimen one of only two well documented ornithocheiroids known from the Nova Olinda Lagerstätte.

Key words: Ornithocheiroidea, pterosaur, taphonomy, Aptian, Cretaceous, Crato Formation, Brazil.

Ross A. Elgin [rosselgin@ hotmail.com] and Eberhard Frey [dinofrey@aol.com], Staatliches Museum für Naturkunde Karlsruhe (SMNK), Abteilung Geologie, Erbprinzenstraße. 13., 76133 Karlsruhe, Germany.

This is an open-access article distributed under the terms of the Creative Commons Attribution License (for details please see creativecommons.org), which permits unrestricted use, distribution, and reproduction in any medium, provided the original author and source are credited. 